\title{
UM ROBÔ SIMULACRO: DAVID
}

\author{
Milene Baldo
}

"A vida da matéria ou é puro sonho, ou mero jogo atómico, que desconhece as conclusões da nossa inteligência e os motivos da nossa emoção. Assim a essência da vida é uma ilusão, uma aparência e ou é só ser ou não ser, e a ilusão e aparência de nada ser, tem que ser não-ser, a vida é a morte."

\section{A FICÇÃO CIENTÍFICA E O TEMA DOS AUTÔMATOS}

Através dos tempos, a literatura, por meio, principalmente, da ficção, sempre serviu ao homem como campo de experimentação daquilo que não ocorria ou não poderia ocorrer no mundo real. Assim, personagens, espaços e realidades paralelas poderiam ser especulados e neles poderse-ia imergir somente pela imaginação. Todas essas produções ligam-se aos seus sujeitos históricos, em razão de apresentarem traços típicos de determinada civilização, com suas diferentes maneiras de se enxergar o mundo, as diferentes culturas, os papéis sociais etc. É o que se pode ver nas histórias de Fiç̧ão Científica, um campo da literatura que reflete o homem do século XX e XXI, rodeado, por um lado, pelos avanços científicos e tecnológicos e, por outro lado, pela reconfiguração de valores e instituições que duraram séculos. 
Este tempo, marcado pelas revoluções industriais e tecnológicas, trouxe consigo uma linha divisória: a máquina, que traz em si as características pertinentes à composição do mundo que se configurou a partir de então, pois alterou não apenas a vida concreta e cotidiana, mas também - ponto mais importante para esta discussão - o imaginário das sociedades modernas. Foi a máquina então que trouxe a possibilidade da criação de um simulacro do ser humano, intuito assinalado claramente pelo romance intitulado Frankenstein ou o moderno Prometeu (1818), de Mary Shelley (1797-1851), aceito por muitos como a obra inaugural do gênero Ficção Científica.

Tais máquinas - presentes em nossa realidade hoje - devem ser vistas como uma espécie de concretização, no mundo moderno, do desejo que sempre acompanhou o homem: tomar dos deuses o poder da geração da vida. É assim que, ao longo da história, alquimistas, cabalistas, engenheiros e tantas outras figuras representativas buscaram formar a vida. Ocorre que em quase todas essas histórias, as novas criaturas, frutos da "sapiência" e investigação puramente humanas, sempre se enquadram como uma nova espécie, a qual, por mais que apresente inteligência, não pode ser associada à inteligência humana, considerada superior, uma vez que faltaria, nas novas criaturas, a emoção, os sentimentos. São estes os principais vetores da criação da experiência própria em relação às sensações suscitadas pelo corpo, o que constitui o humano como indivíduo único, dotado da capacidade de aprender a cada nova sensação, a cada novo contato com o mundo ou com outros seres, o que lhes possibilita a capacidade de ser criativo de construir saberes e ideias. Destarte, tais figuras estão sempre subordinadas aos seres humanos, como escravas, seja por trabalho, dependência, sentimentos ou outros fatores. Algumas dessas projeções figuraram na história da humanidade de tal maneira que influenciaram imaginários de culturas por diversas épocas, sofrendo adaptações e releituras, e perdurando até a atualidade, muitas vezes tendo interferência até na própria realidade.

Inicialmente pensada como um mecanismo qualquer, com capacidade de ações próprias, como mover-se sozinho, a figura do robô sofreu mudanças significativas. No último século, a tecnologia capaz de o criar foi invadida pela antiga busca humana pela produção - e nesse mundo tão capitalista esse vocábulo é bem adequado - de uma criatura sua, um ser "vivo", dotado de inteligência a sua imagem e semelhança. E é sob essa influência que foi concebida a história do robô David, de autoria de Brian Aldiss, a qual serviu de base para o filme Artificial Intelligence (2001), de Spielberg, e que será investigada, pois interessa saber como esta 
obra resolveu ou compreendeu a inserção desta tópica na sociedade e que reflexões ela suscita.

\section{OS TRÊS CONTOS}

A história de David, um superbrinquedo robô em forma de menino, é registrada por Aldiss" em três contos: "Superbrinquedos duram o verão todo", "Superbrinquedos quando vêm o inverno" e "Superbrinquedos em outras estações". O primeiro conto foi publicado pela primeira vez na Harper's Bazaar em dezembro de 1969, já os outros dois foram escritos cerca de 30 anos depois. A razão para este hiato e posterior retomada encontrase na relação que Aldiss desenvolveu com o cineasta Stanley Kubrick. Este comprou os direitos sobre o primeiro conto em 1982 e apresentou ao londrino, antes da aquisição, seu desejo de fazer um filme de conto de fadas moderno, um conto de fadas inserido na Ficção Científica. O conto em pauta, então, foi tomado como "um ótimo começo para uma história mais longa", segundo o próprio escritor revela no prefácio de sua antologia (ALDISS, 2001), o qual inclusive denuncia, pelo título "Tentando agradar", a maneira como se deu este relacionamento.

Logo, torna-se inconcebível pensar que a saga de David possa ser abordada sem a percepção de que Kubrick tornara-se extremamente influente na redação do inverno e das outras estações do robô-menino.

1 Brian Wilson Aldiss é um autor inglês conhecido por sua produção no gênero Ficção Científica. Sua produção engloba, porém, poemas, romances, ensaios, investigação historiográfica e crítica literária. Seu primeiro romance nesse gênero, Criminal Record, foi lançado em 1954. Na Convenção Mundial de FC de 1958, foi intitulado o mais promissor escritor naquela ocasião e ocupou a presidência da Academia Britânica de FC de 1960 a 1966. Junto de Harry Harrison, amigo seu, concebeu o primeiro jornal exclusivo para uma crítica literária de gênero, o Science Fiction Horizons, que não prosperou. Foi homenageado com o título de Grande Mestre em 1999, pela premiação Nebula, da qual também recebeu prêmio em 1965 por The Saliva Tree, e ainda conquistou o Hugo - prêmio que existe desde 1953 e elege, anualmente, as melhores histórias de ficção científica publicadas no ano precedente - em 1962 por Hothouse, como melhor história de fantasia, dentre algumas outras homenagens e méritos. De suas obras, três foram adaptadas para o cinema: Frankenstein Unbound (1990) de Roger Cornan, baseia-se na obra de mesmo nome publicada em 1973; a mais famosa adaptação é Artificial Inteligence (2001) de Steven Spielberg, fundamentada em três contos aqui analisados e a última Brothers of the Head (2006), dirigida por Keith Fulton e Louis Pepe, é baseada no livro homônimo. À parte todo esse panorama histórico, vale ressaltar que Aldiss segue produzindo ainda hoje, seja lançando novas histórias ou fazendo crítica literária, principalmente de FC. 
O gênio indomável do diretor relacionara de pronto a ideia de David à de Pinóquio e, por este motivo, até mesmo presenteou Aldiss com uma obra de Collodi. Aldiss, porém, relutou em aceitar tal comparação. Juntas, as duas mentes não conseguiram desenvolver o projeto mais ambicioso de Kubrick e pararam então de produzi-lo associados. Certo tempo depois, mais precisamente assim que o cineasta faleceu, Aldiss voltouse novamente para o conto e desenvolveu, por fim, sua continuação e desfecho.

\section{3. a. Superbrinquedos duram o verão todo}

"No jardim da sra. Swinton era sempre verão." Assim começa a história de David. Em seguida, o menino aparece, sorrindo "sem dentes" e correndo como qualquer garoto de cinco anos. Ainda nesta cena inicial, é anunciada a tentativa frustrada de Monica de amar David. Terminada a interação com seu "filho", dirige-se à sala e por meio de um controle remoto muda "o comprimento das janelas". O jardim então some e dá lugar ao centro da cidade caracterizado como "cheio de multidões e prédios". Ela fica sozinha.

Tem início o segundo ato. Henry Swinton, esposo de Monica, está em um almoço que reúne os diretores da Synthank, empresa da qual é presidente e que produz "formas de vida sintética", de dinossauros em miniatura a tênias destinadas a serem instaladas nos intestinos para consumir o excesso de comida que o ser humano ingere. Fato que explica a aparência dos presentes, pois todas as pessoas comem e bebem de maneira exagerada, mas têm corpos extremamente esbeltos. Acresce-se a isso o fato de algumas usarem máscaras plásticas no rosto por ser uma moda local. O narrador faz uma observação sobre tal estética, diz que "uma geração mais velha e menos sofisticada teria os considerado todos pessoas bonitas, à exceção dos olhos", pois eram frios e calculistas. O Sr. Swinton inicia seu discurso sobre o lançamento de um novo produto: "uma forma de vida sintética inteligente”, um serviçal que, além de possuir um microcomputador no lugar do cérebro, como os superbrinquedos, teria seus circuitos ligados à carne sintética. Sabe-se, por sua fala, também que a Terra sofre um problema de superpopulação e ao menos três quartos dos seres humanos passam fome, problema, de certo modo, minimizado pelo discurso de Henry, pois parece que aos seus o alimento sobra, causa de problemas de outra natureza, como a obesidade. A narrativa volta novamente à casa dos Swinton, precisamente ao quarto de brinquedos onde se encontram David e Teddy, um ursinho mecânico com um computador interno. O menino está escrevendo frases no papel e pede o auxílio do amigo para continuar, pois não consegue pensar no que dizer. 
É este o cenário inicial desta obra, a qual versará sobre as relações que Monica desenvolve com os dois autômatos em sua casa simulada e as que Henry desenvolve em seu mundo empresarial. Os dois humanos se encontrarão apenas no final da obra, quando ele chega em casa trazendo o novo produto e ela lhe avisa que receberam pelo Ministério da População autorização para terem uma criança.

Este conto apresenta características próprias dos textos do inglês, ou seja, há muitas "lacunas", as quais possibilitam intensas reflexões, a começar pelo primeiro período. De pronto é marcado que o ambiente da residência em que se passa a história tem disparidades com a realidade natural, afinal é sempre verão. Sabe-se depois que na casa dos Swinton, o que se visualiza, como as paisagens do jardim, são imagens provenientes da simulação, pois eles residem em um prédio que não proporciona visão para o mundo externo, dado ser este extremamente "feio" para ser visto, de modo que é melhor apagá-lo e criar a sensação de uma realidade virtual. Esse problema é ainda mais explorado nos diálogos que Henry trava com um colega do trabalho. Em um deles, afirma ser melhor que sua esposa esteja em casa para poder cultivar "belos pensamentos". Ora, parece assim que o contato com o mundo real seria um infortúnio para Monica e a melhor conduta a adotar é trancafiar-se em sua moradia construindo simulações desejáveis.

Nesse sentido, tal irrealidade não se apresenta apenas enquanto relação com o mundo, mas também na relação entre os seres humanos. Paradoxalmente, num mundo superpopuloso, no qual o controle de natalidade tem de ser extremo, Monica, além de seu esposo, tem apenas o contato com duas criaturas autômatas. Os dois são superbrinquedos, mas David é um humanoide e Teddy, apenas uma espécie de brinquedo do primeiro. Eles serviriam como uma forma de entretenimento e contato para a jovem, a qual, assim como muitas outras pessoas, sente-se só e isolada. Seus vazios são preenchidos com esses "companheiros", os quais inclusive podem ser considerados melhores que os humanos. Henry anuncia o novo serviçal androide como alguém que está disposto a ouvir o homem, o que pressupõe certo descaso dos seres humanos com seus iguais, uma falta de empatia na relação homem-homem. Todavia, o drama apresenta-se no momento em que os conflitos de Monica não se mostram apaziguados, pois ela não consegue amar aquele que seria um simulacro de um filho. Parece que, na medida em que há um afastamento do que é real - ao abraçar Teddy, por exemplo, ela apenas sente a vibração do motor -, os seres humanos sentem emoções e sensações menos reais e denotam menor capacidade de expressarem-se como reais, começando a tornarem-se, eles também, menos reais, sentindo-se incompletos por 
não poderem conceber os verdadeiros sentimentos - Monica chora por não poder amar o brinquedo. Uma vez que tudo parece ser simulação, as sensações apresentam-se vazias.

Começa a delinear-se assim uma inversão de papéis. Enquanto Monica e os outros seres humanos começam a expor mais artificialidade em suas ações, sentimentos e aparência, o menino robô começa a indagarse sobre as questões filosóficas próprias da humanidade: o real e o não-real, a falta do amor de mãe etc. Ele começa a expressar sentimentos variados: ora amor, ora repulsa (nas frases, há declaração tanto de amor como de repulsa pelo ursinho). David também aproxima-se do caráter humano metafísico em razão de não ter conhecimento sobre sua própria essência, sobre quem é. Ele não sabe, portanto, que é um ser artificial, não possui informações sobre sua fabricação; a realidade foi, para ele, simulada. Notese que essa é uma condição exatamente humana, pois o homem também se insere num mundo de incertezas sobre sua essência como ser e sobre suas relações com seus iguais, partindo, em decorrência disso, em busca das respostas a essas indagações, movimento similar ao de David. Nessa perspectiva, muito significativa se torna a colocação do brinquedo Teddy em sua última fala do conto, quando afirma que ninguém tem certeza do que significa ser "real".

\section{3. b. Superbrinquedos quando vem o inverno}

Trinta anos depois, a jornada de David é continuada e, muito apropriadamente, começa com a oração "No jardim da senhora Swinton nem sempre fazia verão”. A casa dos Swinton é descrita agora como simulada para o inverno com o uso do programa "Eurinverno". Haveria ali um céu azulado de inverno que "permaneceria o mesmo para sempre" se o programa continuasse a funcionar. Um novo personagem é agora inserido, Jules, o serviçal sintético, provavelmente a surpresa que Henry oferece a Monica no final do primeiro conto. É dito que ele sofrera um upgrade nos últimos tempos e por isso estava com os movimentos de locomoção comprometidos, mas com uma fala mais humana, o que agradava Monica. Esta, novamente, é caracterizada como entediada e entristecida, razão pela qual o serviçal sugere chamar uma amiga, Dora-Belle, para uma visita. A sra. Swinton, depois de negar o conselho de Jules, inicia uma conversa com seu esposo na Ambient, espécie de internet, e este está entusiasmado com uma nova aquisição, a qual poderá tornar a sua empresa a maior do planeta dentre as produtoras de sintéticos, tornando-os extremamente ricos, vantagem que é explorada por Henry como a possibilidade de eles se mudaram para um lugar melhor, desfazerem-se de David e Teddy, adquirirem novos sintéticos e até mesmo uma ilha. 
Desligando a chamada, Monica pede que as duas máquinas, que estavam a brincar muito divertidamente no tanque ornamental congelado, entrem e brinquem dentro de casa, ordem obedecida de imediato e cumprida com o que o narrador classifica de "alegria fingida". Ela os observa com olhar melancólico e, em seguida, volta a ingressar na Ambient, na qual há milhares de pessoas conectadas para discutir questões religiosas, enviando seus pensamentos. Monica então fala para aquela multidão conectada: "Eu preciso de Deus porque fico muito sozinha", "Meu bebê morreu. Mas eu não sei onde Deus está. Talvez ele não visite as cidades". Por esse pronunciamento fica-se sabendo que ela perdera o bebê que fora autorizada a ter. Recebe muitas respostas, ora de teor bastante religioso, ora cético, de pessoas dos mais diversos lugares, ela examina algumas respostas e desliga a Ambient. Depois de alguns devaneios nota que, na parte de cima da casa, onde estão seus brinquedos, há um silêncio profundo, inquietante.

Esta situação inicial será quebrada pelo conflito que ocorre na disputa de atenção dos sintéticos para com sua dona e na discussão deles em relação à sua existência, que levarão a casa a sucumbir, à morte da humana e à descoberta de David sobre a sua consistência robótica. Ao mesmo tempo, a discussão da criação de um cérebro tão complexo quanto o dos seres humanos é desenvolvida no ambiente empresarial de Henry.

Fica evidente que há uma diferença entre os contos, talvez em função da influência dos diálogos com Kubrick, mas também em razão do imaginário que se relaciona a mudanças decorridas no mundo real, ao longo dos anos. A presença de uma rede similar a internet deixa essa afirmação clara. Salvo isto, a saga de David no inverno traz variadas ideias para a compreensão da relação homem-máquina. Assim, num primeiro momento tem-se uma emotiva relação máquina-máquina, representada pela amizade de David e Teddy. Ambos assemelham-se a crianças comuns, que brincam, se divertem e riem muito, características bem retratadas por uma das primeiras cenas, quando eles estão a entreter-se ao assistir um vídeo com uma história que já conheciam há tempos, como as crianças que não se cansam de pedir para que os adultos lhe contem uma mesma história. Nesse sentido, o par David-Teddy caracteriza uma patente amizade com relação de colaboração e cumplicidade.

Ainda na análise desse momento, o fato de Monica irritar-se com essa atitude das máquinas pode ser encarado como uma continuação da pouca empatia que ela guarda para com suas companhias. Talvez o fato de eles continuarem a serem crianças apresente razões para essa distância posta por Monica, pois os dois são criaturas que jamais crescerão. David, 
do ponto de vista da mãe, jamais abandonará sua constituição infantil, será sempre um garoto, nunca mudará. Ele jamais atingirá sua "versão" adulta, agregada de experiências e com novas maneiras de encarar sua constituição, seu próprio modo de ser, assim como nunca possuiu uma versão "bebê". Como seria possível para Monica encará-lo como um verdadeiro filho? A tarefa se coloca tão complexa porque ele nada mais é do que uma imitação do que seria uma criança de cinco anos, podendo ser facilmente descartado, como é sugerido por Henry no começo deste conto.

O diálogo que existe entre Henry Swinton e um outro executivo retoma uma importante discussão aberta no primeiro conto: o fato de a produção dos sintéticos estar acontecendo com cada vez mais ambição. Se no verão eles conseguiram ligar um cérebro sintético à pele de mesma espécie, agora veem-se brigando com aquilo que é criação da natureza, o próprio cérebro humano. A ideia que se deixa transparecer, tomando-se como pressuposto as demais problemáticas trabalhadas na saga, é a de que quanto mais o homem desvenda sua origem, a constituição de seu organismo bioquímico, mais ele se afasta de sua constituição metafísica, diferenciando-se das concepções que pareceriam imanentes ao ser humano e ganhando características artificiais, mais próximas do conceito de máquina.

Não bastasse isso, fica mais evidente neste conto o fato de os Swinton viverem num mundo totalmente artificial. Há a cabine que simula um exercício - uma espécie de videogame como o atual Wii numa escala avançada - e proporciona adrenalina e sensação de realidade. Simula até toda a casa que, sem a simulação, é apenas uma ruína. Há irrefutáveis semelhanças com Matrix (1999), mas ao contrário deste, em Aldiss, "a caverna” fora criada pelos próprios seres humanos e não por máquinas que gostariam de nos dominar. As imagens reais se perderam e o contato do homem com o mundo real também não existe, apenas como projeções de uma realidade. A pensar assim, constatar-se-á que, como os robôs, as percepções sentidas pelo homem nesse mundo virtual, na mesma medida, não podem ser consideradas plenamente verdadeiras. $\mathrm{O}$ homem aproxima-se novamente da máquina, enquanto esta continua no caminho reverso.

A princípio, ressurgem os questionamentos de David sobre sua própria constituição: ele faz parte do mundo natural como os golfinhos ou não? Em momento posterior, ao verem o serviçal Jules destroçado diante de si, totalmente destruído, cena em que se pode ver os mecanismos internos que o animam, tanto David quanto Teddy não demonstram identificação com aquela criatura, consideram-na mesmo descartável, 
pois, uma vez ela que seja um androide - não é real, não é única, mas um exemplo de uma série de iguais -, um novo exemplar idêntico pode ser adquirido novamente, pois trata-se de um produto. Até que ocorre o momento mais sofrível da narração. David choca-se com sua própria natureza, por perceber-se um autômato, um produto, portanto, descartável assim como Jules e não único, não humano, não real. Seu grito de horror e suas palavras de desespero lhe conferem descomunal sensação de desconforto. Análogo a Frankenstein, a não aceitação da criatura existe e é exposta como momento tenebroso, mas a aversão do momento provém do próprio robô e é dirigida a si mesmo, quando se percebe criatura. Há, neste instante, uma libertação do robô desse mundo de simulação, é como se começasse a sair da caverna de Platão, o que lhe causa dor; até então, o que ele acreditava ser real internamente não passava de falsidade. É tomado de todas as pulsões que existem em si, tanto que não as consegue controlar, berra, corre, grita, não consegue falar, tudo isso por não aceitar a sua constituição. Suas reações mostram-se similares às de um homem diante de uma notícia trágica como aquela.

Porém, o desmanche do teatro ainda continua a acontecer, e quando ele destrói o controle central da casa, tudo aquilo que conhecia como realidade externa, cai por terra, literalmente, de modo que absolutamente nada do que via antes permaneceu. Tudo sumiu e o mundo real se mostrou, finalmente, uma realidade nada parecida com a anterior. Como que num início de vida, ele é quem partirá numa jornada pelas sensações verdadeiras e a primeira já ocorre ali, quando toca uma rosa. Ao que tudo indica, o menino-robô agora aceitará, pela lógica, a sua verdadeira essência, mas isto não ocorre, visto que ele ainda diz à mãe morta que é humano, pois tem sentimentos como as pessoas de verdade. Dessa fala, depreende-se um conceito essencial: para David, o fato de ter sentimentos humanos - a tristeza, o amor etc. - o autoriza a ser também humano, logo, depreende-se que a humanidade não estaria no fato de se possuir um organismo específico, mas sim, na experiência da essência metafísica de um humano.

\section{3. c. Superbrinquedos em outras estações}

A jornada de David pelas outras estações começa com um diálogo entre o menino robô e uma criatura intitulada Fixer-Mixer - descrita como um robô com muitos braços e pernas, semelhante a uma aranha -, enquanto ambos viajam a caminho da cidade de Refugo. A conversa se inicia com um questionamento do menino-robô sobre o tamanho da criatura, muito maior que o dele, e ela lhe responde que é grande porque o mundo o é. David então responde "O mundo ficou grande depois que 
a mamãe morreu.” Fixer-Mixer diz-lhe que máquinas não têm mãe e o pequeno retorque que não é uma máquina.

A cena seguinte apresenta a cidade de Refugo, lugar para onde vão todas as máquinas que não têm mais serventia para a humanidade, desde calculadoras até robôs. Um reduto abarrotado de disformidades, de autômatos que se mexiam, que podiam e ainda os que poderiam, talvez, se mexer, como acentua o narrador. Ali, as máquinas auxiliavam umas as outras na tentativa de consertarem-se ou para qualquer utilidade necessária. David aconchegou-se a um "servitor de supermercado" numa espécie de caixa com refrigeração. Ao reclamar que gostaria da presença de Teddy, o outro lhe questiona o motivo deste ser tão especial e David afirma que os dois brincavam muito. O servitor pergunta se Teddy era humano e o menino apenas informa que era como ele. A conversa encerra-se com a asserção de que ambos eram então apenas máquinas. Um tempo depois, David também é inquirido sobre a quem pertencia e diz apenas que "tinha um pai chamado Henry Swinton”, mas que este passava a maior parte do tempo viajando.

Tem início outra cena, na qual Henry Swinton se encontra em um hotel a beira mar, onde está hospedado a negócios com outros três sócios. Apresenta-se a paisagem do mar, mas o pai de David não pode ouvir o barulho das ondas porque há um vidro triplo que o protege do som. Ele se senta de costas para a janela que possui vista para a praia, talvez para se concentrar mais na reunião que está tendo e quem sabe imaginar uma forma mais rápida de chegar à presidência da World-synth-Claws, a nova empresa da qual faz parte. Em seguida, sabe-se que ele está a propor um investimento em Marte, o qual recebe forte oposição dos outros representantes à mesa, por ser de um custo extremamente elevado, além do fato de a empresa ter pedido percentuais de lucro. Mas o Sr. Swinton demonstra estar, além de convencido de sua ideia, bastante arrogante em relação a ela, pois argumenta que seus opositores não têm tino para o negócio como ele, que foi, por exemplo, quem propôs levar sintéticos para a Ásia, onde obteve grandioso sucesso. Agora, o projeto que propõe consiste em levar uma "sintassistência" ao planeta vermelho, com a qual controlaria toda a sua atmosfera e, uma vez que a humanidade depende de ar para sobreviver, era como se eles se tornassem donos do próprio planeta. Tal ideia é veementemente rejeitada e um dos sócios usa mesmo de grosseria para com Henry. A reunião é encerrada.

Como nos contos anteriores, a história será apresentada em dois ambientes distintos: aquele em que vive David e aquele em que vive Henry. O primeiro agora terá de desenvolver uma convivência, sem a presença da "mãe" ou do "amigo", com outras máquinas marcadas pela 
brutalidade humana numa espécie de lixão para robôs. Já Henry passará de grande empreendedor a desempregado, o que lhe causará mudanças internas significativas e fará com que se volte novamente para observar o mundo não-simulado que existe em torno de si e mesmo as criaturas que desprezara até então.

Nas outras estações, a relação da convivência entre máquinas é especialmente trabalhada no ambiente da cidade de Refugo. Se antes esta perspectiva só era percebida do ponto de vista dos amigos David-Teddy, agora David amplia sua rede de relações. E este interagiré retratado também quanto aos outros autômatos relacionando-se não necessariamente com o menino, os quais parecem criar uma espécie de convivência com mútua colaboração, esta característica pode permitir a compreensão de que haja alguma empatia por parte dos seres mecânicos para consigo mesmos, uma vez eles não tenham sido programados para executar funções ou ter pensamentos em relação ao outro.

No entanto, ainda assim, David parece destoar de todos eles, não se encaixando em sua classe, assertiva que se confirma na própria fala do menino no final do conto e que vai se firmando ao longo dos diálogos que ele estabelece com as máquinas. Primeiro, na diferença de ter ou não uma mãe com relação ao Fixer-mixer; depois, em relação ao servitor, que além de considerá-lo máquina, pouca importância dá ao fato de ele sentir falta de Teddy assim como os Devlins, robôs dançantes, que não conseguem compreender a necessidade da presença de um outro ser para que haja qualquer maior importância na execução de sua programação; e, por último, na diferença em relação ao autômato recém-chegado, quando não há qualquer compreensão de mensagens por parte de ambos. $\mathrm{O}$ ponto que faz com que ele destoe de maneira radical das outras máquinas é a falta que sente de Teddy: ele construiu uma memória junto daquele mecanismo a qual de algum modo lhe faz ter vontade de que o ursinho pudesse estar presente ali novamente para continuarem a viver bons momentos de risos e diversão. David possui a empatia, a necessidade de ter alguém, um outro, e, em função disso, a ausência dessa existência lhe incomoda. Nisso, ele contrasta com os Devlins, por exemplo, os quais precisam apenas reproduzir seu programa de dança, assim como os golens (NAZÁRIO, 1998), independente de alguém assisti-los, o que é absolutamente irrelevante. Ao que tudo indica, o menino-robô tem realmente um programa de simulação extremamente próximo do que seria uma criança verdadeira.

Notável, nesse conto, é o fato de ele não apresentar sensação pela perda de Monica, mas sim por Teddy, deixando um questionamento em relação a todo amor que ele demonstrava por ela. Além do mais, quando 
indagado sobre seu dono, cita apenas o nome de Henry como seu pai. Uma possível resposta talvez seja o fato de que ele deve possuir um programa para o "amor", mas não necessariamente vinculado a alguém ou alguma coisa (ama a mãe e David).

Interessante mudança também évista no trabalho com a personagem de Henry Swinton, o qual representava nos contos anteriores a figura da sociedade exacerbada de tecnologia e do mundo empresarial, traço que é modificado em outras estações, uma vez que, mesmo estando novamente em uma reunião comercial, na qual tratava de mais um projeto ambicioso, desta vez a "compra" de um próprio planeta, ao invés de ascensão, presencia-se a derrocada de sua carreira profissional, ambiciosa. Porém, à medida que ele desprende-se ou perde esse espírito de empresário tomado de busca infinita pelo lucro ou novas criações lucrativas, começa a olhar para o mundo real e como consequência para o mundo interior. Assim, quando está com angústia por perceber que não estão concordando com seus planos, sai para passear em uma praia real e deixa-se tocar o próprio organismo pela areia, abandonando o impedimento que o tênis poderia ser para esse contato. É o primeiro sinal de muitos de um retorno ao mundo das sensações reais e não simuladas, como o vislumbrar a janela para a qual antes ficava de costas, o ouvir o som do mar, que antes era abafado pelas janelas. Tanto assim se dá que ele começa a refletir sobre si mesmo e sobre os seus - Monica e o filho de brinquedo -, quando se dá conta de suas próprias ações, faz o retorno a sua essência humana, resgatando o "filho", pois busca David em Refugo. Recupera também a amizade e o sentido de existir, o que lhe causa felicidade. Perde-se a apatia que sempre pairava em torno das ações dele, principalmente no mundo dos negócios.

Além disso, o desfecho da história traz uma nova perspectiva destoante dos caminhos mais percorridos por histórias de ficção científica com robôs: no golem, a criatura é desmontada e os humanos voltam a ser a predominância; em Frankenstein (1818), o criador morre, mas a criatura também se elimina e o homem volta a sobrepor-se à criação; por fim, em Pinóquio (COLLODI, 2002), a criatura é transformada em ser humano, tornando-se real, o humano também se sobressai. A saga de David, contudo, apresenta um final com uma espécie de conciliação. Existem a cidade humana, na qual vivem homens e as máquinas são serviçais; a cidade Refugo, onde as máquinas "vivem" por si mesmas, auxiliando-se umas as outras; e, finalmente, o microcosmo que envolve David, uma espécie de "nova-existência", um ser no plano metafísico, pois provado fica que não se encaixa na categorização de máquina, tendo em vista se diferenciar destas, mas que também não é humano como os outros, pois 
apresenta um corpo mecânico que sentirá o mundo por meio mecanismos diferentes do homem comum - ele mesmo se dá conta disso ao ver os outros mil de sua série -, nesse sentido não seria mais propriedade de Henry, mas seu filho. Ambas as formas de vida continuam, portanto, coexistindo e se auxiliando, integrando uma mesma família e não havendo sobreposições de uma a outra.

\section{DAVID COMO SIMULACRO}

Já é certamente conhecida a tentativa humana de concepção de seres que constituam simulações dos seres humanos, uma vez sejam concebidos como criaturas a nossa imagem e semelhança, não enquanto organismo apenas, mas enquanto a capacidade cognitiva de processar dados e informações produzindo pensamentos. David é assim encarado como um autômato dos mais próximos dessa reprodução de um ser humano, por não conhecer sua essência, não saber como foi concebido e outras semelhanças. Tendo em vista essas postulações, e para tratar corretamente as ideias de simulação, cópia, semelhanças e simulacro, serão buscadas suas raízes na antiga Grécia de Platão, que investigou este assunto.

Em Platão, precisamos primeiramente recorrer ao mito da caverna, plenamente explorado pela filosofia, pela literatura e claramente pela ficção científica. Platão narra o mito da caverna em seu diálogo com Glauco, no Livro VII de $A$ República tendo em vista fazer com que seu interlocutor perceba que os tragediógrafos, na verdade, não poderiam ser conhecedores daquilo tudo que contavam, pois apenas simulavam situações e não as viviam de fato. O objetivo desta analogia é poder mostrar o conceito platônico sobre a compreensão do mundo, que seria dividido em dois: o mundo inteligível, concebido pelo sagrado, e o mundo sensível, no qual vive a humanidade. Desse modo, o homem viveria no mundo físico, e possuiria um corpo para interagir e sentir tudo a sua volta. Entretanto, tratar-se-ia apenas de um mundo de sombras, de projeções da verdade das coisas, a qual somente seria encontrada no mundo das ideias. Mas este homem não sairia em tamanha desvantagem, apesar de possuir um corpo sensível, pois unida a ele está a alma, pertencente ao mundo das ideias e que sofreria um processo de encarnação na matéria, o que implica na obstrução de sua memória sobre o que existia no verdadeiro mundo. $\mathrm{O}$ homem que foge da caverna seria $\mathrm{o}$ filósofo que poderia compartilhar o conhecimento adquirido sobre a verdade, o essencial, com seus semelhantes, fazer-lhes relembrar aquilo que já sabem.

Nesse sentido, tudo o que se apresenta a nós é considerado cópia de seu verdadeiro modelo no mundo das ideias, mas há ligação com a 
sua essência pela semelhança que guarda com ela. Já quando se busca no mundo sensível a reprodução de algum destes objetos já presentes no mundo sensível ter-se-ia o simulacro.

Glauco - Parece que o nome que lhe conviria melhor é de o imitador daquilo de que os outros dois são os artífices.

Sócrates - Que seja. Chamas portanto, imitador ao autor de uma produção afastada três graus da natureza. (PLATÃO, 2004, p. 324)

Assim, o simulacro seria uma cópia da cópia e estaria três estágios longe da verdadeira essência, apresentando-se então como disforme, pois se perde a preservação da semelhança, e o simulacro passa a ser o grau inferior na escala essência (real), cópia (sensível), simulacro, ideia que é bem esclarecida por Chauí (2002):

O primeiro grau é o simulacro ou a simulação, a eikasia, palavra da mesma raiz de eikón (imagem, ícone), indicando aquelas coisas que são apreendidas numa percepção de segunda mão, isto é, são as cópias ou as imagens de uma coisa sensível, como os reflexos no espelho ou na água, as narrativas dos poetas, as pinturas, as esculturas e as imagens na memória. Esse primeiro nível ou modo de conhecer costuma ser chamando pelos comentadores de imaginação, entendida como conhecimento por imagens, as quais são cópias da coisa sensível. Assim, a poesia, a pintura, a escultura, a retórica pertencem a esse nível mais baixo do conhecimento porque nos oferecem uma imagem da coisa sensível e não a própria coisa sensível. A eikásia é uma conjectura feita a partir dos reflexos e das cópias das coisas sensíveis.

Nesse sentido, o homem pode reproduzir, no mundo sensível, tudo o que existia como verdade no mundo das ideias. Não poderia reproduzir apenas a própria existência que é ele, uma vez que, apesar de estar com o corpo no mundo sensível, esta matéria é animada pela presença de uma substância do mundo inteligível: a alma, a qual é obra apenas do sagrado.

Como visto, o mundo existia como possibilidade de vivência sensível para o homem, o qual era único porque racional, distinguindo-se da natureza. Ocorre que o advento do robô-David reorganizaria a sequência linear de existência proposta por Platão, já que o robô seria a cópia ou um simulacro. Parece ser verdade, contudo, que o robô não implica apenas uma reprodução do organismo do ser humano, mas também numa simulação da intelectualidade, da inteligência, do que lhe é abstrato, fruto de sua alma incorporada, assim essa busca pela feitura da máquina também concebe o que se entende hoje por inteligência artificial, e, no caso de David, busca-se também a reprodução das emoções, de maneira que o autômato possa ser completo. Nessa perspectiva, o robô estaria 
aproximando-se da cópia, pois o modelo para a criatura seria a alma, essência pura. Todavia, deve-se lembrar de que o homem, o inventor, não possui plena compreensão do que seja sua própria essência abstrata, sua alma, ou suas emoções, uma vez tenha uma percepção apenas obstruída de tudo isso, o que o obrigaria a conhecer apenas uma parte, não tendo então conhecimento da própria constituição enquanto ser - emoções, sentimentos ou mesmo inteligência - como poderá reproduzir o que não conhece? Destarte, ao reproduzir numa criatura aquilo que não concebe bem, nada mais estaria fazendo do que um simulacro, cópia apenas das aparências e não da verdadeira essência.

Desse modo, quandoas máquinas são concebidas, sendo simulacros, são disformes. Não alcançam o que concebemos como essência, pois toda a memória que possuem não é construída em função das experiências que vivenciaram num longo período de amadurecimento que se inicia na infância e segue até a morte. Elas apenas possuem uma memória instaurada e reproduzem aos estímulos de algo implantando que não contribui para lhes constituir como seres únicos, como sujeitos históricos. Ademais, como é o caso de algumas máquinas que aparecem nos contos (os Devlins), ao executaram seus programas, as funções para as quais foram concebidas, estas criaturas não possuiriam a consciência, a flexibilização pelo aprendizado da experiência e o livre-arbítrio pela escolha de não fazê-lo ou de fazer algo diferente - como não têm a função "dizer adeus" não se despedem da criatura a sua frente, David. Talvez isso explique o fato de boa parte das criaturas nos contos não conseguir controlar-se e cometer atos incitados por suas pulsões internas, pois lhes falta o arcabouço da cultura, a formação do ego dada na convivência com o outro para equilibrar o ser entre as pulsões titânicas inerentes a este simulacro, balanceamento que constituiria um verdadeiro ser dionisíaco dual.

Assim, o robô David, quando comparadoàs outras máquinas presentes nos contos, apresentar-se-ia como uma nova forma de existência, um estágio posterior ao da máquina desprovida de consciência. Ele constituiria um simulacro na medida em que ainda apresenta-se como uma tentativa de reprodução de um ser humano, de um menino. No entanto esse simulacro deve ser compreendido como uma realidade.

Seria preciso eliminar para este ser o conceito de realidade segundo Platão, a qual era um produto da criação do sagrado, pois aqui há uma verdadeira libertação deste plano. O David-simulacro seria uma forma de existência emancipada de todas as concepções existentes até então, pois ele colocar-se-ia dominando suas próprias escolhas, pois transita na sua própria linha histórica e passa a ter o domínio das suas ações, uma vez tenha 
vivenciado, tido contato com o mundo sensível por meio de seu organismo e tenha agregado novas informações, imagens, sensações ao seu cérebro artificial, constituindo a partir daí uma existência única. Ele passaria a ser não mais uma simulação, uma reprodução de outra forma de ser, constituindo agora uma nova forma de existir no mundo sensível agregando construções metafísicas desprovidas de correspondência com o sagrado, e sendo, como consequência, real. Tal revisão da concepção da realidade fica clara em Baudrillard:

Os modelos já não constituem uma transcendência ou uma projeção, já não constituem um imaginário relativamente ao real, são eles próprios antecipação ficcional - são imanentes, e não criam, pois, nenhuma espécie de transcendência imaginária. O campo aberto é o da simulação no sentido cibernético, isto é, o da manipulação em todos os sentidos destes modelos (cenários, realização de situações simuladas, etc.), mas então nada distingue esta operação da gestão e da própria operação do real: já não há ficção.

A realidade poderia ultrapassar a ficção: seria o sinal mais seguro de uma sobrevalorização possível do imaginário. Mas o real não poderia ultrapassar o modelo, do qual é apenas o álibi.

O imaginário era o álibi do real, num mundo dominado pelo princípio de realidade. Hoje em dia, é o real que se torna simulação. E é paradoxalmente o real que se tornou a nossa verdadeira utopia - mas uma utopia que já não é da ordem do possível, aquele com que já não pode senão sonhar-se como um objecto perdido. (1991, p. 152-153).

O menino-robô representaria, como diz o personagem do Professor Hobby no filme ${ }^{2}$, o primeiro de uma nova espécie. Uma forma que traria uma ruptura das direções antes sedimentadas, porque se trata de uma criatura híbrida e mesmo pós-humana, que poderia proporcionar não apenas a proliferação de outros como ela, mas uma modificação na própria constituição daquele do qual se fez simulacro: o ser humano (como começa a acontecer na realidade, quando homens apresentam muitas partes de seu corpo construídas sinteticamente e não partes naturais). Assim, enquanto se olha para a concepção de existência do robô David, de Aldiss, o movimento se voltaria para a própria humanidade, que se encontraria também numa ruptura de concepção de si mesma, pois passaria a ter de admitir a possibilidade de uma vida sintética similarà sua, o que o eliminaria

2 A. I. Artificial Intelligence. Direção: Steven Spielberg. Produção: Kathleen Kennedy, Steven Spielberg e Bonnie Curtis. Intérpretes: Haley Joel Osment, Jude Law, Frances O'Connor, Brendan Gleeson, William Hurt e outros. Roteiro: Steven Spielberg. [S.1] Amblin/Stanley Kubrick, DreamWorks SKG, Warner Bros, Stanley Kubrick Productions, 2001, 1 DVD, (146 min), colorido. 
de vez como parte única de um plano metafísico superior: o da constituição como ser racional.

\section{CONSIDERAÇÕES FINAIS}

Fica claro no rápido exame que se faz de alguns contos de ficção científica como esta literatura se torna imprescindível como campo para a experimentação das necessárias reflexões sobre o devir. Antes, construíamos deuses gregos para explicarmos a existência humana, hoje, buscamos no simulacro do robô as respostas para a condição de seres pensantes. Ao projetarmos uma criação de um similar, procuramos encontrar nossa própria essência, tanto do ser orgânico quanto do ser abstrato.

A trilogia Superbrinquedos de Brian Aldiss mostra-se, portanto, como narrativa fundamental enquanto possibilita esse exercício do pensar, pois David apresenta muitos dos problemas humanos: a busca pelos sentimentos do outro e pelo outro, a aceitação enquanto indivíduo único e, ao mesmo tempo, pertencente àquela coletividade, as questões sobre a própria identidade, além de proporcionar uma reflexão sobre as consequências possíveis, havendo a construção destes simulacros, tanto para as criaturas quando para o homem no que tange à perda da sua própria humanidade.

\section{REFERÊNCIAS BIBLIOGRÁFICAS}

ALDISS, Brian. Superbrinquedos duram o verão todo: e outros contos de um tempo futuro. Tradução de Beth Vieira. São Paulo: Companhia das Letras, 2001. 270p.

BAUDILLARD, Jean. Simulacros e Simulações. Tradução de Maria João da Costa Pereira. Lisboa: Relógio D’Água, 1991. 201 p.

CHAUÍ, Marilena. A teoria do conhecimento na República. In: Introdução à história da filosofia: dos pré-socráticos e Aristóteles. Vol. 1, 2. ed., revista e ampliada, São Paulo, Companhia das Letras, 2002, 249-256 p.

COLLING, Michael R. Brian Aldiss. [S.I]: Borgo P, 1986.

COLlODI, Carlo. As aventuras de Pinóquio. Tradução e ilustrações de Gabriella Rinaldi. São Paulo: Iluminuras, 2002, 156 p.

DELEUZE, Gilles. Platão e o simulacro. In: Lógica do sentido. 4ed. São Paulo: 


$$
400 \text { - Remate de Males } 32.2
$$

GOLDSSCHMIDT, Victor. Os Diálogos de Platão: Estrutura e Método dialético. Tradução de Dion Davi Macedo. São Paulo: Edições Loyola, 2002. 356 p.

NAZÁRIO, Luiz. Da natureza dos Monstros. São Paulo: Arte \& Ciência, 1998. 304 p.

PLATÃO. A República. Tradução de Enrico Corvisieri. São Paulo: Nova Cultural, 2004. 352 p. (Coleção Os Pensadores).

- Diálogos: O banquete, Fédon, Sofista, Político. Tradução de José Cavalcante de Souza, Jorge Paleikat e João Cruz Costa. 4 ed. São Paulo: Nova Cultural, 1987. 266 p. (Coleção Os Pensadores)

SHELLEY, Mary. Frankestein ou o Moderno Prometeu. Tradução de Éverton Ralph. São Paulo: Publifolha, 1998. 224 p. (Biblioteca Folha - Clássicos da Literatura Universal). 